\title{
Effect of lactic acid bacteria and yeast supplementation on anti- nutritional factors and chemical composition of fermented total mixed ration containing cottonseed meal or rapeseed meal
}

\author{
Hassan Ali Yusuf ${ }^{1,2}$, Minyu Piao ${ }^{1}$, Tao Ma ${ }^{1}$, Ruiying Huo ${ }^{1}$, and Yan $\mathrm{Tu}^{1, *}$
}

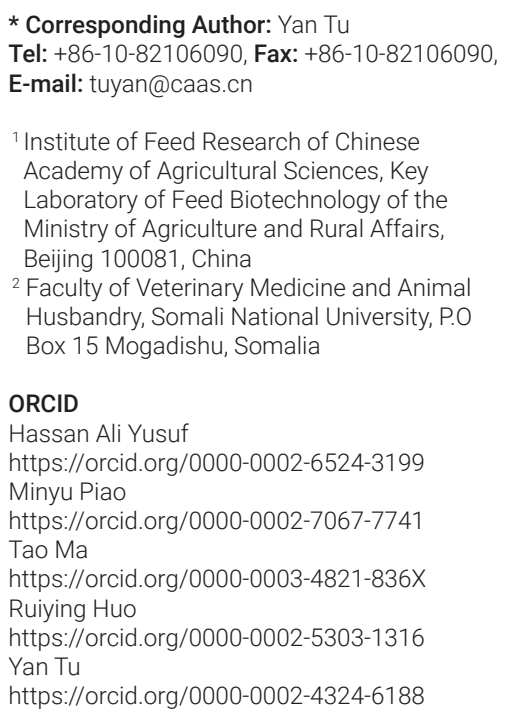

Submitted Jun 13, 2021; Revised Jul 28, 2021; Accepted Sept 5, 2021
Objective: This study aimed to determine the appropriate supplementation level of lactic acid bacteria (LAB; Lactobacillus plantarum and Bacillus clausii), yeast (Saccharomyces cariocanus and Wickerhamomyces anomalus) for degrading free gossypol and glucosinolate in the fermented total mixed ration (TMR) containing cottonseed meal (CSM) or rapeseed meal (RSM), to improve the utilization efficiency of these protein sources.

Methods: For LAB, L. plantarum or B. clausii was inoculated at $1.0 \times 10^{8}, 1.0 \times 10^{9}, 1.0 \times 10^{10}$, and $1.0 \times 10^{11}$ colony-forming unit (CFU)/kg dry matter (DM), respectively. For yeast, $S$. cariocanus or $W$. anomalus was inoculated at $5 \times 10^{6}, 5 \times 10^{7}, 5 \times 10^{8}$, and $5 \times 10^{9} \mathrm{CFU} / \mathrm{kg} \mathrm{DM}$, respectively. The TMR had $50 \%$ moisture and was incubated at $30^{\circ} \mathrm{C}$ for $48 \mathrm{~h}$. After fermentation, the chemical compositions, and the contents of free gossypol and glucosinolate were determined.

Results: The results showed that the concentration of free gossypol content was reduced $(\mathrm{p}<0.05)$, while that of the crude protein content was increased $(\mathrm{p}<0.05)$ in the TMR containing CSM inoculated by B. clausii $\left(1 \times 10^{9} \mathrm{CFU} / \mathrm{kg} \mathrm{DM}\right)$ or S. cariocanus $\left(5 \times 10^{9} \mathrm{CFU} / \mathrm{kg} \mathrm{DM}\right)$. Similarly, the content of glucosinolate was lowered $(\mathrm{p}<0.05)$ and the crude protein content was increased $(\mathrm{p}<0.05)$ in TMR containing RSM inoculated with B. clausii $\left(1 \times 10^{10} \mathrm{CFU} / \mathrm{kg}\right.$ $\mathrm{DM})$ or S. cariocanus $\left(5 \times 10^{9} \mathrm{CFU} / \mathrm{g} \mathrm{DM}\right)$.

Conclusion: This study confirmed that inclusion of B. clausii with $1.0 \times 10^{9}$ or $1.0 \times 10^{10}$ $\mathrm{CFU} / \mathrm{kg}$ DM, or S. cariocanus $\left(5 \times 10^{9} \mathrm{CFU} / \mathrm{kg} \mathrm{DM}\right)$ to TMR containing CSM/RSM improved the nutritional value and decreased the contents of anti-nutritional factors.

Keywords: Cottonseed Meal; Free Gossypol; Glucosinolates; Lactic Acid Bacteria; Rapeseed Meal; Total Mixed Ration; Yeast

\section{INTRODUCTION}

With the rising demand for protein in the feed industry and the rising cost of soybean meal (SBM), it is becoming increasingly necessary to substitute other sources of protein. Therefore, the interest in research for alternative plant proteins to replace SBM in animal nutrition has grown. Two products that we are interested in are cottonseed meal (CSM) and rapeseed meal (RSM) because they are locally available and lower cost than SBM (on protein basis). Cottonseed meal is a by-product of cottonseed oil extraction, which contains approximately $34 \%$ to $40 \%$ of crude protein (CP), $11 \%$ of crude fiber (CF), as well as vitamin $\mathrm{B}$ and organic phosphorus [1]. Nevertheless, the use of CSM in animal diet is restricted due to the presence of free gossypol (FG), a toxic pigment which may have adverse effects on animals' growth, reproduction, intestinal development, and lead to internal organ abnormalities [2,3]. Rapeseed meal is a by-product of rapeseed crushing after the oil extraction process and contains high protein level (34\% to 38\%) with a well-balanced amino 
acid composition and $25 \%$ to $30 \%$ neutral detergent fiber (NDF) [4]. Rapeseed meal protein is nutritionally comparable to soy protein and has more S-amino acids than many other plant proteins [5]. Nevertheless, the inclusion of RSM in animal diets is also limited due to anti-nutritional factors and high fiber levels [6]. Although RSM has a nutritional value comparable to SBM, it contains glucosinolate, sinapine, and the derivatives taninin and phytic acid and CF which may negatively affect animals' growth performance, health, and general welfare [7].

Several approaches have been used to decrease the antinutritional factors of CSM, such as calcium hydroxide [8], chemical treatment with ferrous sulfate [9], and microbial fermentation [10]. To reduce the anti-nutritional factors of RSM, methods such as inactivation of myrosinase, solvent extraction, steam removal, and liquidation have been applied. Still, such methods also have some disadvantages including loss of protein, high expense, commercial relative unimportance, and environmental pollution [11]. Fermented total mixed ration (FTMR) is an effective way to optimize nutrient utilization and feed storage life. Fermentation of total mixed ration (TMR) generated by microorganisms has been broadly accepted and commonly employed to enhance the feed quality [12]. An additive combination of TMR containing Lactobacillus casei (L. casei) TH14 with fermented sugarcane bagasse had significant effects on mid-lactation Holstein Friesian cows' intake, digestibility, rumen ecology, and milk output [13]. Fermenting feed with microbes is viewed as a promising solution $[14,15]$, as it may be effective in reducing anti-nutritional components and increasing the amino acid content [16]. However, few studies tested if microbial fermentation can improve the nutritive value of the feed by enhancing the bioavailability of nutrients and decreasing the contents of anti-nutritional factors [17]. In China, fermented feed is usually manufactured by fermentation with an aim to reduce anti-nutritional factors in feed components such as CSM [18] and RSM [19].

Using lactic acid-producing bacteria (LAB) is an efficient method to reduce the contents of anti-nutritional elements in CSM and increase its nutritional value [20,21]. For example, Tang et al [22] reported that fermentation with Bacillus subtilis (B. subtilis) BJ-1 could reduce the amount of FG in CSM and that dietary inclusion of fermented CSM at a rate of $12 \%$ can promote the immunity and growth performance of animals. Previously published research has demonstrated that substituting CSM fermented by B. subtilis BJ-1 for SBM enhanced the growth performance and intestinal morphology while increasing the abundance of beneficial bacteria of broiler chickens [16,23]. According to Cherdthong et al [24], L. casei TH14 in combination with molasses or molasses plus cellulose produces superior outcomes by preventing $\mathrm{CP}$ degradation during fermentation, while increasing the digestibility of dry matter (DM) and organic matter, the rumen bacterial population, and concentration of propionic acid. Lactobacillus plantarum (LP) has been supplemented to TMR with silage and had improved rumen fermentation characteristics [25]. Bacillus clausii (B. clausii) is a gram-positive spore-forming microorganism, when administered in sufficient amounts, confers health advantages on the host [26].

Yeast is abundant in nature and easy to be cultured in large quantities [17]. Saccharomycetes has been widely used to reduce the contents of anti-nutritional factors of diet through fermentation and phytic acid degradation with phytase [27]. Additionally, yeast may increase the $\mathrm{CP}$ and mineral content of plant-based meals [28]. Most researchers have conducted their studies using Saccharomyces cerevisiae (S. cerevisiae). Although S. cerevisiae has numerous advantages, several drawbacks have been observed, especially low cell biomass [29]. Under aerobic circumstances, S. cerevisiae ferment alcohol rather than produces biomass [30]. This limits animals' access to nutritious yeast biomasses like protein, vital amino acids, and vitamins. As a result, it is critical to broaden the field of research and to strengthen the study of the use of additional yeast strains. Due to the limited amount of information available, Saccharomyces cariocanus (S. cariocanus) and Wickerhamomyces anomalus (W. anomalus) may be alternative options. However, little information is available on the fermented TMR containing CSM or RSM with LAB (e.g., L. plantarum and B. clausii) or yeast (e.g. S. cariocanus and $W$. anomalus) supplementation. The objectives of this research were to select the suitable level of LAB (L. plantarum and B. clausii) and yeast (S. cariocanus and W. anomalus), and to assess the effects of inoculants on the chemical compositions and anti-nutritional factors in fermented TMR. We hypothesized that the inoculation of LAB or yeast at an appropriate level to CSM or RSM might reduce the anti-nutritional factors while increasing the nutritional value.

\section{MATERIALS AND METHODS}

\section{Experimental design and treatments}

The experiment was performed from June to Dec 2020 at Laboratory of Ruminant Feed Nutrition Innovation, Institute of Feed Research of Chinese Academy of Agricultural Sciences, Beijing, China. One-way design was used to evaluate the effect of four different inoculum dosage levels of $L A B$ or yeast on anti-nutritional factors and chemical composition of FTMR containing CSM or rapeseed. Treatments including control with no inoculant; F control, fermented control without inoculum; LP1, inoculated with $L$. plantarum with $1 \times 10^{8}$ colony-forming units (CFU)/kg DM; LP2, inoculated with $L$. plantarum with $1 \times 10^{9} \mathrm{CFU} / \mathrm{kg} \mathrm{DM}$; LP3, inoculated with L. plantarum with $1 \times 10^{10} \mathrm{CFU} / \mathrm{kg} \mathrm{DM}$; LP4, inoculated with $L$. plantarum with $1 \times 10^{11} \mathrm{CFU} / \mathrm{kg} \mathrm{DM}$, or BC1, inoculated with $B$. clausii with $1 \times 10^{8} \mathrm{CFU} / \mathrm{kg} \mathrm{DM}$; BC2, inoculated 
with $B$. clausii with $1 \times 10^{9} \mathrm{CFU} / \mathrm{kg} \mathrm{DM}$; BC3, inoculated with B. clausii with $1 \times 10^{10} \mathrm{CFU} / \mathrm{kg} \mathrm{DM}$; BC4, inoculated with $B$. clausii with $1 \times 10^{11} \mathrm{CFU} / \mathrm{kg}$ DM. Similarly treatments of inoculum dosage levels of yeast including control with no inoculant; F control, fermented control without inoculum; SC1, inoculated with S. cariocanus with $5 \times 10^{6} \mathrm{CFU} / \mathrm{kg} \mathrm{DM}$; SC2, inoculated with $S$. cariocanus with $5 \times 10^{7} \mathrm{CFU} / \mathrm{kg} \mathrm{DM}$; SC3, inoculated with $S$. cariocanus with $5 \times 10^{8} \mathrm{CFU} / \mathrm{kg} \mathrm{DM}$; SC4, inoculated with S. cariocanus with $5 \times 10^{9} \mathrm{CFU} / \mathrm{kg} \mathrm{DM}$; or WA1, inoculated with $W$. anomalus with $5 \times 10^{6} \mathrm{CFU} / \mathrm{kg} \mathrm{DM}$; WA2, inoculated with $W$. anomalus with $5 \times 10^{7} \mathrm{CFU} / \mathrm{kg} \mathrm{DM}$; WA3, inoculated with $W$. anomalus with $5 \times 10^{8} \mathrm{CFU} / \mathrm{kg} \mathrm{DM}$; WA4, inoculated with $W$. anomalus with $5 \times 10^{9} \mathrm{CFU} / \mathrm{kg} \mathrm{DM}$.

\section{Experimental materials}

L. plantarum, B. clausii, S. cariocanus, and W. anomalus used in this study were purchased from a local company (Gaotang Huanong Bioengineering Co. Ltd., Shandong, China). The CSM and RSM used as fermentation substrate were collected from a local feed manufacturer (Dadi Feed Company, Chengdu, Sichuang, China).

\section{Real-time quantitative polymerase chain reaction} analysis of inoculants

Total bacterial and yeast primers were used to quantify the $\mathrm{LAB}$ and yeast, respectively. The primer for total bacterial detection was designed based on 16S rRNA V4 region (515F: GTGYCAGCMGCCGCGGTAA and 806R: GGACTACN VGGGTWTCTAAT). The primer for total yeast was designed based on ITS region (ITS1F CTTGTCATTTAGGA AGTAA and ITS2R GCTGCGTTTCATCGATGATGC). In the same quantitative polymerase chain reaction (qPCR) system, the amount of both sample and standard sample was 1 $\mu \mathrm{L}$. Then, the samples were mixed, centrifuged, and divided into 96 well PCR plates. Each sample had three replications for each gene. An initial denaturation at $95^{\circ} \mathrm{C}$ for 10 minutes was followed by 40 denaturation cycles at $95^{\circ} \mathrm{C}$ for 20 seconds, followed by annealing at $60^{\circ} \mathrm{C}$ for 30 seconds. Extractions of DNA and RNA were conducted using Power Soil DNA extraction kit: 142579, Qiagen and Mini RNA extraction kit 217004, Qiagen following the manufacturer's instructions of protocol (Life Technologies, Beijing, China). The concentrations of DNA and RNA of LAB were determined together, and the units are shown as copies/g.

\section{Preparation and fermentation of TMR containing CSM} and RSM with inoculants

The CSM and RSM were used as a fermentation substrate in TMR. The L. plantarum or B. clausii were added into TMR containing CSM or RSM at $1.0 \times 10^{8}, 1.0 \times 10^{9}, 1.0 \times 10^{10}$, and $1.0 \times 10^{11} \mathrm{CFU} / \mathrm{kg}$ DM, respectively as shown in Figure 1. S. cariocanus or W. anomalus were added into TMR contain- ing CSM or RSM at $5 \times 10^{6}, 5 \times 10^{7}, 5 \times 10^{8}$, and $5 \times 10^{9} \mathrm{CFU} / \mathrm{kg}$ DM, respectively $[31,32]$. The TMR was mixed thoroughly and uniformly, and moisture content was adjusted to $50 \%$. The ingredients and chemical compositions of the diets are shown in Table 1. A vacuum sealer machine was used to remove air from the fermentation plastic bags. TMR were incubated in an incubator at $30^{\circ} \mathrm{C}$ for $48 \mathrm{~h}$. Following completion of fermentation, the inoculated samples were dried at $65^{\circ} \mathrm{C}$ for $48 \mathrm{~h}$, cooled, and ground to a size of $2 \mathrm{~mm}$. The dried samples were transferred into new plastic bags and stored at $-20^{\circ} \mathrm{C}$ for later analysis. Triplicate plastic bags were used for each treatment.

\section{Measurements}

Chemical composition: TMR with fermented CSM or RSM, fermented control (control group that was not inoculated but fermented) and original control (neither inoculated nor fermented) were made and prepared for subsequent analysis. Samples were ground to pass through a 1-mm sieve size for analysis of DM, CP, and ether extract (EE) according to AOAC [33]. According to Van Soest et al [34], NDF and acid detergent fiber (ADF) were determined.

Anti-nutritional factors analysis: The FG was determined using the official method of the American Oil Chemists Society [35]. Free gossypol was determined by the presence of 3-amino-1-propanol, a mixture of isopropyl alcohol and n-hexane was used to extract FG, and aniline was used to convert gossypol to aniline cotton phenol, and the colorimetric determination was carried out at the maximum absorption of the spectrophotometer at the wavelength of $440 \mathrm{~nm}$ of a spectrophotometer. Two grams of TMR with CSM sample was put in a $250 \mathrm{~mL}$ Erlenmeyer flask with stopper, 20 glass beads, and pipette. The tube was filled with $50 \mathrm{~mL}$ of solvent, closed the bottle, put it in the shaker, and was oscillated for $1 \mathrm{~h}$. A dry filter was used and then was covered with funnel glass to reduce the solvent volatilization. The first few drops of filtrate were discarded and the remaining was collected using $100 \mathrm{~mL}$ Erlenmeyer flask with a stopper.

Calculation formula

$$
X=\frac{A \times 1,250 \times 1,000}{a \times m \times V}=\frac{A \times 1.25}{a m V} \times 10^{6}
$$

In the formula: $\mathrm{X}=\mathrm{FG}$ content $(\mathrm{mg} / \mathrm{kg}) ; \mathrm{A}=$ correct the absorbance; $\mathrm{m}=$ sample quality $(\mathrm{g}) ; \mathrm{V}=$ the volume of filtrate for determination $(\mathrm{mL}) ; \mathrm{a}=$ mass absorption coefficient, $\mathrm{FG}$ is $62.5 \mathrm{~cm}^{-1} \mathrm{~g}^{-1} \mathrm{~L}$.

Correspondingly, glucosinolates of the TMR with RSM were determined using palladium chloride [36]. Briefly, 0.2 $\mathrm{g}$ TMR with RSM was powdered in a mortar and added to a graduated test tube containing $10 \mathrm{~mL}$ boiling water. The mixtures were thoroughly shaken and heated for 30 minutes in 


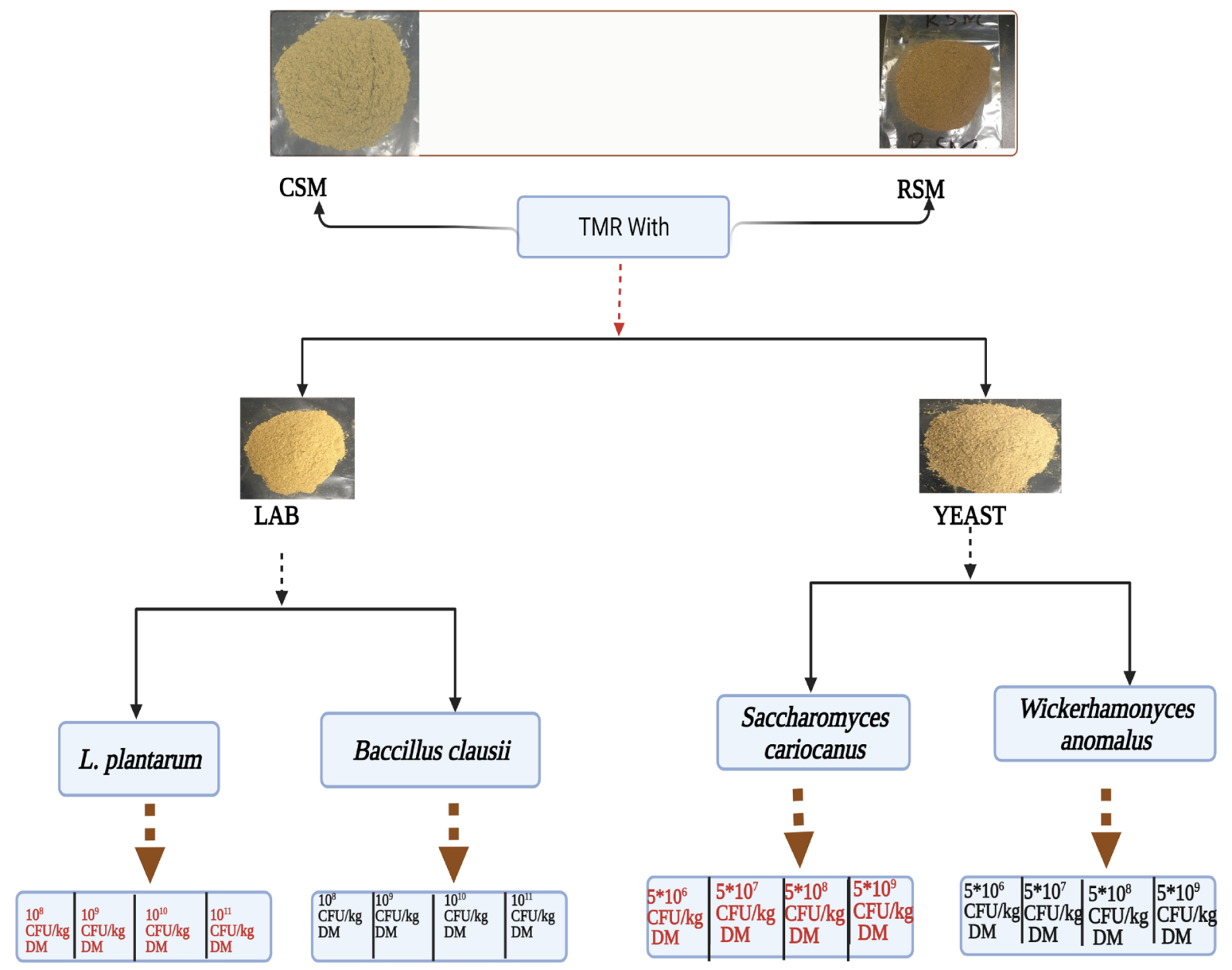

Figure 1. Schematic illustration of the design of LAB and yeast of inoculating TMR with CSM or RSM. TMR, total mixed ration; CSM, cottonseed meal; RSM, rapeseed meal; LAB, lactic acid bacteria; CFU, colony-forming units; DM, dry matter.

Table 1. Ingredients and nutrient composition of TMR with CSM or RSM (\% of DM)

\begin{tabular}{lcc}
\hline Items & TMR with CSM & TMR with RSM \\
\hline Ingredient & 33.55 & 33.48 \\
Corn & 12 & 12 \\
Wheat bran & 10 & 0 \\
CSM & 0 & 10 \\
RSM & 20 & 20 \\
Whole corn silage & 20 & 20 \\
Cornstalk & 0.3 & 0.3 \\
Fat powder & 0.15 & 0.22 \\
Urea & 4 & 4 \\
Premix & 100 & 100 \\
Total & & \\
Chemical composition & 51.77 & 52.72 \\
DM (fresh basis) & 13.61 & 12.68 \\
CP & 2.37 & 1.910 \\
EE & 38.17 & 34.32 \\
NDF & 20.69 & 17.26 \\
ADF & & \\
\hline
\end{tabular}

TMR, total mixed ration; CSM, cottonseed meal; RSM, Rapeseed meal; $D M$, dry matter; CP, crude protein; EE, ether extract; NDF, neutral detergent fiber; ADF, acid detergent fiber. water bath before being diluted to ten milliliters. Following centrifugation, $2 \mathrm{~mL}$ of TMR with RSM extract suspension was pipetted to a graduated tube containing $4 \mathrm{~mL}$ of $0.15 \%$ of sodium carboxymethyl cellulose and shaken well. Then, 2 $\mathrm{mL}$ of $8 \mathrm{mmol} / \mathrm{L}$ palladium chloride color was added. After vigorous stirring, the mixed solutions were kept at $22^{\circ} \mathrm{C} \pm 3^{\circ} \mathrm{C}$ for $2 \mathrm{~h}$. The absorption at $540 \mathrm{~nm}$ (A) was determined using sodium carboxymethyl cellulose as the reference material and a blank solution as the standard solution. The glucosinolate content was determined using absorbance $\mathrm{A}$, which is proportional to the glucosinolate content as ascertained by the standard curve. Standard curve: $\mathrm{A}=\mathrm{Kx}+\mathrm{b}$.

$$
\text { Glucosinolate content X }(\mu \mathrm{mol} / \mathrm{g})=(\mathrm{A}-\mathrm{b}) / \mathrm{k} \text {. }
$$

$\mathrm{X}=$ glucosinolate content; $\mathrm{A}=$ absorbance value; $\mathrm{k}$ and $\mathrm{b}=$ fixed values.

\section{Statistical analysis}

Data were analyzed with SPSS version 23.0 (IBM Corp., Ar- 
A.

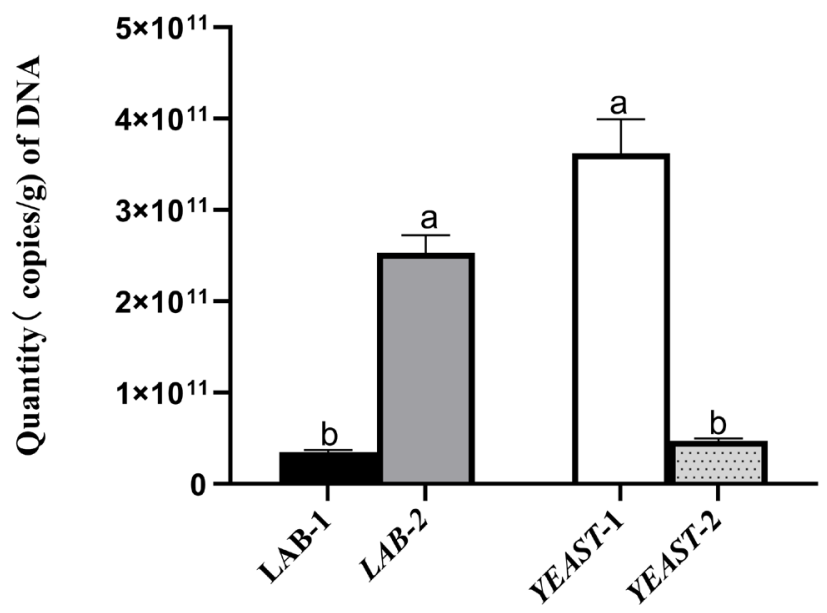

B

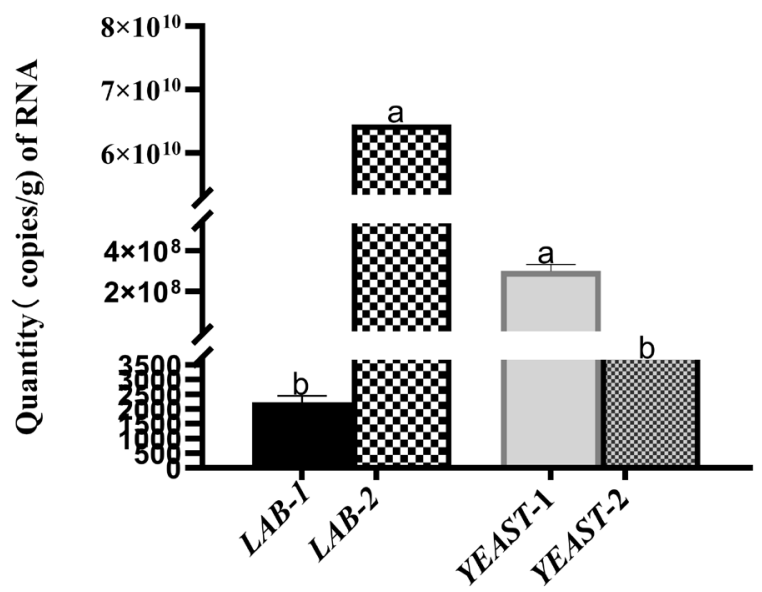

Figure 2. Comparison of the quantities (copy/g) of (A) DNA and (B) RNA of LAB and yeast. The DNA and RNA levels were determined by real-time PCR. LAB-1, Lactobacillus plantarum; LAB-2, Bacillus clausii; Yeast-1, Saccharomyces cariocanus; Yeast-2, Wickerhamomyces anomalus; PCR, polymerase chain reaction.

monk, NY, USA). One-way analysis of variance was used to analyze the effects of inoculants on the chemical composition and anti-nutritional factors. The significance of differences between mean values was assessed using Tukey's multiple comparisons. Differences between the treatments were considered significant if $\mathrm{p}<0.05$, and results were visualized using GraphPad Prism version 8.3 (San Diego, CA, USA).

\section{RESULTS}

Real-time quantitative polymerase chain reaction analysis

The DNA and RNA levels of four strains were determined by real-time PCR. B. clausii had higher $(\mathrm{p}<0.05)$ DNA and RNA levels compared to L. plantarum. In addition, S. cariocanus showed higher $(\mathrm{p}<0.05)$ DNA and RNA levels than $W$. anomalus (Figure $2 \mathrm{~A}$ and $2 \mathrm{~B}$ ).

\section{Chemical composition of fermented TMR with CSM or RSM}

In the fermented TMR containing CSM with LAB supplementation, the contents of DM, EE, and NDF did not differ ( $p>0.05$ ) among treatments (Table 2). Fermentation with $L$. plantarum and B. clausii increased CP content $(\mathrm{p}<0.05)$. All groups inoculated with $B$. clausii at $1 \times 10^{9} \mathrm{CFU} / \mathrm{kg} \mathrm{DM}$ showed the highest $\mathrm{CP}$ content $(15.24 \%)$. The $\mathrm{CP}$ contents of $\mathrm{BC} 1$ (B. clausii with $\left.1 \times 10^{8} \mathrm{CFU} / \mathrm{k} \mathrm{g} \mathrm{DM}\right)$ and $\mathrm{BC} 2$ (B. clausii with $\left.1 \times 10^{9} \mathrm{CFU} / \mathrm{kg} \mathrm{DM}\right)$ were higher $(\mathrm{p}<0.05)$ than that of control group. The ADF of LP4 (L. plantarum with $1 \times 10^{11} \mathrm{CFU} / \mathrm{kg}$ $\mathrm{DM})$ and $\mathrm{BC} 4\left(\right.$ B. clausii with $\left.1 \times 10^{11} \mathrm{CFU} / \mathrm{k} \mathrm{g} \mathrm{DM}\right)$ showed the lowest reduction $(p<0.05)$ than that of control group. In the fermented TMR containing CSM with yeast supplementation, the contents of DM, CP, EE, NDF, and ADF did not differ ( $p>0.05$ ) among treatments (Table 3). Nonetheless, the CP content of SC4 (S. cariocanus with $5 \times 10^{9} \mathrm{CFU} / \mathrm{kg} \mathrm{DM}$ ) was numerically higher than that of other treatments.

Table 2. Effect of inoculated Lactobacillus plantarum or Bacillus clausii on chemical composition of TMR with CSM (\% DM)

\begin{tabular}{|c|c|c|c|c|c|c|c|c|c|c|c|c|}
\hline \multirow{2}{*}{ Items } & \multirow{2}{*}{ Control } & \multirow{2}{*}{ F control } & \multicolumn{4}{|c|}{ Lactobacillus Plantarum ${ }^{1)}$} & \multicolumn{4}{|c|}{ Bacillus clausii $^{1)}$} & \multirow{2}{*}{ SEM } & \multirow{2}{*}{ p-value } \\
\hline & & & LP1 & LP2 & LP3 & LP4 & $\mathrm{BC} 1$ & $\mathrm{BC} 2$ & BC3 & BC4 & & \\
\hline DM (fresh basis) & 51.77 & 47.53 & 50.09 & 51.06 & 51.65 & 50.69 & 47.17 & 46.53 & 48.51 & 50.19 & 0.499 & 0.107 \\
\hline $\mathrm{CP}$ & $13.61^{\mathrm{a}}$ & $14.64^{\mathrm{ab}}$ & $14.09^{\mathrm{ab}}$ & $14.29^{a b}$ & $14.32^{\mathrm{ab}}$ & $14.23^{\mathrm{ab}}$ & $15.05^{b}$ & $15.24^{b}$ & $14.61^{\mathrm{ab}}$ & $14.63^{\mathrm{ab}}$ & 0.116 & 0.009 \\
\hline EE & 2.37 & 2.57 & 2.54 & 2.31 & 3.24 & 2.70 & 3.33 & 3.04 & 2.69 & 3.17 & 0.141 & 0.777 \\
\hline NDF & 38.17 & 35.34 & 35.14 & 33.34 & 34.47 & 34.92 & 35.74 & 37.48 & 35.57 & 37.32 & 0.401 & 0.162 \\
\hline ADF & $20.69^{a}$ & $17.77^{\mathrm{ab}}$ & $16.67^{b}$ & $16.34^{b}$ & $15.38^{b}$ & $15.99^{b}$ & $16.67^{b}$ & $17.72^{\mathrm{ab}}$ & $16.48^{b}$ & $16.39^{b}$ & 0.329 & 0.007 \\
\hline
\end{tabular}

TMR, total mixed ration; CSM, cottonseed meal; DM, dry matter; SEM, pooled standard error of means; CP, crude protein; EE, ether extract; NDF, neutral detergent fiber; ADF, acid detergent fiber.

1) Treatments including control with no inoculant; F control, fermented control without inoculum; LP1, Lactobacillus plantarum with $1 \times 10^{8} \mathrm{CFU} / \mathrm{kg}$ DM; LP2, Lactobacillus plantarum with $1 \times 10^{9} \mathrm{CFU} / \mathrm{kg}$ DM; LP3, Lactobacillus plantarum with $1 \times 10^{10} \mathrm{CFU} / \mathrm{kg}$ DM; LP4, Lactobacillus plantarum with $1 \times 10^{11} \mathrm{CFU} / \mathrm{kg}$ $\mathrm{DM}$; $\mathrm{BC} 1$, Bacillus clausii with $1 \times 10^{8} \mathrm{CFU} / \mathrm{kg} \mathrm{DM} ; \mathrm{BC} 2$, Bacillus clausii with $1 \times 10^{9} \mathrm{CFU} / \mathrm{kg} \mathrm{DM}$; BC3, Bacillus clausii with $1 \times 10^{10} \mathrm{CFU} / \mathrm{kg}$ DM; BC4, Bacillus clausii with $1 \times 10^{11} \mathrm{CFU} / \mathrm{kg}$ DM; CFU, colony-forming units.

a,b Means in the same row with different superscripts differed $(p<0.05)$. 
Table 3. Effect of yeast inoculation levels on chemical composition of TMR with CSM (\% DM basis)

\begin{tabular}{|c|c|c|c|c|c|c|c|c|c|c|c|c|}
\hline \multirow{2}{*}{ Items } & \multirow{2}{*}{ Control } & \multirow{2}{*}{ F control } & \multicolumn{4}{|c|}{ Saccharomyces cariocanus ${ }^{1)}$} & \multicolumn{4}{|c|}{ Wickerhamomyces anomalus ${ }^{1)}$} & \multirow{2}{*}{ SEM } & \multirow{2}{*}{ p-value } \\
\hline & & & SC1 & SC2 & SC3 & SC4 & WA1 & WA2 & WA3 & WA4 & & \\
\hline DM (fresh basis) & 51.77 & 47.53 & 49.17 & 49.28 & 48.44 & 48.09 & 53.09 & 47.37 & 47.99 & 49.36 & 0.495 & 0.146 \\
\hline $\mathrm{CP}$ & 13.61 & 14.64 & 14.35 & 14.73 & 15.14 & 15.96 & 15.11 & 15.27 & 15.54 & 14.55 & 0.181 & 0.180 \\
\hline EE & 2.37 & 2.57 & 3.45 & 2.62 & 2.25 & 2.59 & 2.45 & 2.30 & 2.73 & 2.42 & 0.132 & 0.793 \\
\hline NDF & 38.17 & 35.34 & 34.02 & 32.95 & 34.21 & 34.30 & 35.35 & 34.43 & 34.62 & 33.02 & 0.405 & 0.192 \\
\hline ADF & 20.69 & 17.77 & 16.91 & 19.06 & 17.44 & 18.76 & 17.81 & 17.10 & 18.50 & 17.11 & 0.352 & 0.374 \\
\hline
\end{tabular}

TMR, total mixed ration; CSM, cottonseed meal; DM, dry matter; SEM, pooled standard error of means; CP, crude protein; EE, ether extract; NDF, neutral detergent fiber; ADF, acid detergent fiber.

1) Treatments including control with no inoculant, F control, fermented without inoculum; SC1, Saccharomyces cariocanus with $5 \times 10^{6} \mathrm{CFU} / \mathrm{kg}$ DM; SC2, Saccharomyces cariocanus with $5 \times 10^{7} \mathrm{CFU} / \mathrm{kg}$ DM; SC3, Saccharomyces cariocanus with $5 \times 10^{8} \mathrm{CFU} / \mathrm{kg}$ DM SC4; Saccharomyces cariocanus with $5 \times 10^{9}$ CFU/kg DM; WA1, Wickerhamomyces anomalus with $5 \times 10^{6} \mathrm{CFU} / \mathrm{kg}$ DM; WA2, Wickerhamomyces anomalus with $5 \times 10^{7} \mathrm{CFU} / \mathrm{kg}$ DM; WA3, Wickerhamomyces anomalus with $5 \times 10^{8} \mathrm{CFU} / \mathrm{kg}$ DM; WA4, Wickerhamomyces anomalus with $5 \times 10^{9} \mathrm{CFU} / \mathrm{kg} \mathrm{DM}$; CFU, colony-forming units.

As shown in Table 4, in the fermented TMR containing RSM with LAB supplementation, the DM, CP, and NDF contents differ $(\mathrm{p}<0.05)$ among treatments. The treatment inoculated with $B$. clausii at $1 \times 10^{10} \mathrm{CFU} / \mathrm{kg}$ DM showed the highest $\mathrm{CP}$ content $(\mathrm{p}<0.05)$. In the meantime, the treatments inoculated with $B$. clausii at $1 \times 10^{9}$ and $1 \times 10^{11} \mathrm{CFU} / \mathrm{kg} \mathrm{DM}$ showed the highest NDF content $(\mathrm{p}<0.05)$. In the fermented TMR containing RSM with yeast supplementation, only the
$\mathrm{CP}$ and NDF contents differ $(\mathrm{p}<0.01)$ among treatments, which were lowest in the control group (Table 5).

\section{Anti-nutritional factors of TMR with CSM or RSM}

As shown in Table 6, the detoxification efficiency of FG varied with different types and levels of strains. Microbial inoculation decreased $(\mathrm{p}<0.05)$ FG levels during the fermentation. The detoxification efficiency of $B$. clausii were much higher

Table 4. Effect of Inoculated Lactobacillus Plantarum or Bacillus clausii on chemical composition of TMR with RSM (\% DM basis)

\begin{tabular}{|c|c|c|c|c|c|c|c|c|c|c|c|c|}
\hline \multirow{2}{*}{ Items } & \multirow{2}{*}{ Control } & \multirow{2}{*}{ F control } & \multicolumn{4}{|c|}{ Lactobacillus plantarum¹) } & \multicolumn{4}{|c|}{ Bacillus clausii'1) } & \multirow{2}{*}{ SEM } & \multirow{2}{*}{ p-value } \\
\hline & & & LP1 & LP2 & LP3 & LP4 & BC1 & BC2 & $\mathrm{BC} 3$ & BC4 & & \\
\hline DM (fresh basis) & 52.72 & 49.90 & 49.72 & 48.84 & 49.61 & 50.61 & 49.31 & 49.32 & 48.34 & 49.70 & 0.344 & 0.289 \\
\hline $\mathrm{CP}$ & $12.68^{b}$ & $13.33^{\mathrm{ab}}$ & $13.49^{\mathrm{ab}}$ & $13.62^{\mathrm{ab}}$ & $13.34^{\mathrm{ab}}$ & $13.23^{\mathrm{ab}}$ & $13.35^{\mathrm{ab}}$ & $13.31^{\mathrm{ab}}$ & $13.82^{\mathrm{a}}$ & $13.43^{\mathrm{ab}}$ & 0.071 & 0.045 \\
\hline EE & 1.91 & 2.39 & 1.95 & 1.97 & 2.00 & 1.54 & 2.31 & 2.09 & 2.08 & 1.975 & 0.100 & 0.902 \\
\hline NDF & $34.32^{b}$ & $38.61^{\mathrm{ab}}$ & $37.26^{\mathrm{ab}}$ & $37.91^{\mathrm{ab}}$ & $37.83^{\mathrm{ab}}$ & $37.00^{\mathrm{ab}}$ & $38.29^{\mathrm{ab}}$ & $39.22^{a}$ & $37.78^{\mathrm{ab}}$ & $39.25^{\mathrm{a}}$ & 0.342 & 0.043 \\
\hline ADF & 17.26 & 19.64 & 18.95 & 22.13 & 19.91 & 18.95 & 20.48 & 19.62 & 19.14 & 19.88 & 0.327 & 0.127 \\
\hline
\end{tabular}

TMR, total mixed ration; RSM, rapeseed meal; DM, dry matter; SEM, pooled standard error of means; CP, crude protein; EE, ether extract; NDF, neutral detergent fiber; ADF, acid detergent fiber.

1) Treatments including control with no inoculant, F control, fermented without inoculum; LP1, Lactobacillus plantarum with $1 \times 10^{8} \mathrm{CFU} / \mathrm{kg}$ DM; LP2, LaCtobacillus plantarum with $1 \times 10^{9} \mathrm{CFU} / \mathrm{kg} \mathrm{DM}$; LP3, Lactobacillus plantarum with $1 \times 10^{10} \mathrm{CFU} / \mathrm{kg} \mathrm{DM}$; LP4, Lactobacillus plantarum with $1 \times 10^{11} \mathrm{CFU} / \mathrm{kg}$ DM; $\mathrm{BC} 1$, Bacillus clausii with $1 \times 10^{8} \mathrm{CFU} / \mathrm{kg}$ DM; BC2, Bacillus clausii with $1 \times 10^{9} \mathrm{CFU} / \mathrm{kg} \mathrm{DM;} \mathrm{BC3,} \mathrm{Bacillus} \mathrm{clausii} \mathrm{with} 1 \times 10^{10} \mathrm{CFU} / \mathrm{kg} \mathrm{DM}$; BC4, Bacillus clausii with $1 \times 10^{11} \mathrm{CFU} / \mathrm{kg} \mathrm{DM}$; CFU, colony-forming units.

a,b Means in the same row with different superscripts differed $(p<0.05)$.

Table 5. Effect of yeast inoculation levels on chemical composition of fermented TMR with RSM (\% DM basis)

\begin{tabular}{|c|c|c|c|c|c|c|c|c|c|c|c|c|}
\hline \multirow{2}{*}{ Items } & \multirow{2}{*}{ Control } & \multirow{2}{*}{ F control } & \multicolumn{4}{|c|}{ Saccharomyces cariocanus ${ }^{1)}$} & \multicolumn{4}{|c|}{ Wickerhamomyces anomalus ${ }^{1)}$} & \multirow{2}{*}{ SEM } & \multirow{2}{*}{ p-value } \\
\hline & & & SC1 & Sc2 & SC3 & SC4 & WA1 & WA2 & WA3 & WA4 & & \\
\hline DM (fresh basis) & 52.72 & 49.90 & 49.09 & 48.79 & 48.76 & 48.72 & 48.99 & 49.71 & 48.44 & 48.13 & 0.351 & 0.160 \\
\hline $\mathrm{CP}$ & $12.68^{b}$ & $13.33^{\mathrm{ab}}$ & $13.46^{\mathrm{ab}}$ & $13.55^{\mathrm{ab}}$ & $13.66^{\mathrm{a}}$ & $13.94^{\mathrm{a}}$ & $13.59^{\mathrm{a}}$ & $13.62^{\mathrm{a}}$ & $13.69^{a}$ & $14.11^{\mathrm{a}}$ & 0.082 & 0.002 \\
\hline EE & 1.91 & 2.39 & 1.77 & 2.08 & 2.16 & 1.94 & 2.31 & 1.50 & 2.01 & 2.52 & 0.089 & 0.306 \\
\hline NDF & $34.32^{b}$ & $38.61^{\mathrm{ab}}$ & $36.57^{\mathrm{ab}}$ & $39.66^{\mathrm{a}}$ & $37.97^{\mathrm{ab}}$ & $37.38^{\mathrm{ab}}$ & $38.44^{\mathrm{ab}}$ & $38.89^{\mathrm{ab}}$ & $37.77^{\mathrm{ab}}$ & $39.82^{a}$ & 0.385 & 0.033 \\
\hline ADF & 17.26 & 19.64 & 20.39 & 19.96 & 20.90 & 18.99 & 19.90 & 19.85 & 20.00 & 19.79 & 0.243 & 0.063 \\
\hline
\end{tabular}

TMR, total mixed ration; RSM, rapeseed meal; DM, dry matter; SEM, pooled standard error of means; CP, crude protein; EE, ether extract; NDF, neutral detergent fiber; ADF, acid detergent fiber.

1) Treatments including control with no inoculant, F control, fermented control without inoculum; SC1, Saccharomyces cariocanus with $5 \times 10^{6} \mathrm{CFU} / \mathrm{kg}$ DM; SC2, Saccharomyces cariocanus with $5 \times 10^{7}$ CFU/kg DM; SC3, Saccharomyces cariocanus with $5 \times 10^{8}$ CFU/kg DM; SC4, Saccharomyces cariocanus with $5 \times 10^{9} \mathrm{CFU} / \mathrm{kg}$ DM; WA1, Wickerhamomyces anomalus with $5 \times 10^{6} \mathrm{CFU} / \mathrm{kg} \mathrm{DM}$; WA2, Wickerhamomyces anomalus with $5 \times 10^{7} \mathrm{CFU} / \mathrm{kg}$ DM; WA3, Wickerhamomyces anomalus with $5 \times 10^{8} \mathrm{CFU} / \mathrm{kg}$ DM; WA4, Wickerhamomyces anomalus with $5 \times 10^{9} \mathrm{CFU} / \mathrm{kg} \mathrm{DM}$; CFU, colony-forming units.

$a, b$ Means in the same row with different superscripts differed $(p<0.05)$. 
Table 6. Effect of lactic acid bacteria strains on free gossypol/glucosinolate degradation (as-DM basis)

\begin{tabular}{|c|c|c|c|c|c|c|c|c|c|c|c|c|}
\hline \multirow{2}{*}{ Items } & \multirow{2}{*}{ Control } & \multirow{2}{*}{ F control } & \multicolumn{4}{|c|}{ Lactobacillus plantarum ${ }^{1)}$} & \multicolumn{4}{|c|}{ Bacillus clasusii ${ }^{1)}$} & \multirow{2}{*}{ SEM } & \multirow{2}{*}{ p-value } \\
\hline & & & LP1 & LP2 & LP3 & LP4 & BC1 & $\mathrm{BC2}$ & $\mathrm{BC} 3$ & BC4 & & \\
\hline \multicolumn{13}{|l|}{ CSM-based TMR } \\
\hline \multicolumn{13}{|l|}{ RSM-based TMR } \\
\hline GSLs $(\mu \mathrm{mol} / \mathrm{g})$ & $18.45^{\mathrm{a}}$ & $7.71^{\mathrm{b}}$ & $8.13^{b}$ & $7.11^{b}$ & $5.91^{\text {bc }}$ & $6.20^{\mathrm{bc}}$ & $6.86^{\mathrm{b}}$ & $6.21^{\mathrm{bc}}$ & $5.86^{\mathrm{bc}}$ & $3.86^{\mathrm{C}}$ & 0.74 & $<0.001$ \\
\hline \multicolumn{13}{|c|}{$\begin{array}{l}\text { DM, dry matter; SEM, pooled standard error of means; CSM, cottonseed meal; TMR, total mixed ration; FG, free gossypol; RSM, rapeseed meal; GSLs, glu- } \\
\text { cosinolates. } \\
\text { 1) Treatments including control with no inoculant, F control, fermented control without inoculum; LP1, Lactobacillus plantarum with } 1 \times 10^{8} \mathrm{CFU} / \mathrm{kg} \text { DM; LP2, } \\
\text { Lactobacillus plantarum with } 1 \times 10^{9} \mathrm{CFU} / \mathrm{kg} \mathrm{DM} \text {; LP3, Lactobacillus plantarum with } 1 \times 10^{10} \mathrm{CFU} / \mathrm{kg} \text { DM; LP4, Lactobacillus plantarum with } 1 \times 10^{11} \mathrm{CFU} / \mathrm{kg} \\
\text { DM; BC1, Bacillus clausii with } 1 \times 10^{8} \mathrm{CFU} / \mathrm{kg} \text { DM; BC2, Bacillus clausii with } 1 \times 10^{9} \mathrm{CFU} / \mathrm{kg} \mathrm{DM} \text {; BC3, Bacillus clausii with } 1 \times 10^{10} \mathrm{CFU} / \mathrm{kg} \text { DM; BC4, Bacillus } \\
\text { clausii with } 1 \times 10^{11} \mathrm{CFU} / \mathrm{kg} \mathrm{DM;} \mathrm{CFU,} \mathrm{colony-forming} \mathrm{units.} \\
\text { a-c Means in the same row with different superscripts differed (p<0.05). }\end{array}$} \\
\hline
\end{tabular}

than that of L. plantarum. Compared with control group, the levels of glucosinolate were lower $(\mathrm{p}<0.05)$ in BC4 (B. clausii with $\left.1.0 \times 10^{11} \mathrm{CFU} / \mathrm{kg} \mathrm{DM}\right), \mathrm{BC} 3$ (B. clausii with $1.0 \times 10^{10}$ $\mathrm{CFU} / \mathrm{kg} \mathrm{DM}), \mathrm{BC} 2$ (B. clausii with $\left.1.0 \times 10^{9} \mathrm{CFU} / \mathrm{kg} \mathrm{DM}\right)$, BC1 (B. clausii with $1.0 \times 10^{8} \mathrm{CFU} / \mathrm{kg}$ DM), LP1 (L. plantarum with $1.0 \times 10^{8} \mathrm{CFU} / \mathrm{kg} \mathrm{DM}$ ), LP2 (L. plantarum with $1.0 \times 10^{9}$ CFU/kg DM), LP3 (L. plantarum with $\left.1.0 \times 10^{10} \mathrm{CFU} / \mathrm{kg} \mathrm{DM}\right)$, and LP4 (L. plantarum with $\left.1.0 \times 10^{11} \mathrm{CFU} / \mathrm{kg} \mathrm{DM}\right)$, but not compared to the fermented control. B. clausii inoculation with $1.0 \times 10^{11} \mathrm{CFU} / \mathrm{kg}$ DM showed the lowest glucosinolates content (18.45 to 3.86) compared with all treatments inoculated with L. plantarum or B. clausii. In comparison, the RSMbased TMR with $B$. clausii at $1.0 \times 10^{10} \mathrm{CFU} / \mathrm{kg}$ DM decreased glucosinolate content (18.45 to 5.86).

On the other hand, there were significant differences $(\mathrm{p}<$ 0.05 ) in the content of FG with $S$. cariocanus and $W$. anomalus (Table 7). The inoculation with $S$. cariocanus or W. anomalus led to significant reduction of FG content $(\mathrm{p}<0.01)$. Relative to the other, SC3 (S. cariocanus with $5 \times 10^{8} \mathrm{CFU} / \mathrm{kg} \mathrm{DM}$ ), SC4 (S. cariocanus with $\left.5 \times 10^{9} \mathrm{CFU} / \mathrm{kg} \mathrm{DM}\right)$, WA2 (W. anomalus with $5 \times 10^{7} \mathrm{CFU} / \mathrm{kg} \mathrm{DM}$ ), and WA4 (W. anomalus with $5 \times 10^{9}$ $\mathrm{CFU} / \mathrm{kg} \mathrm{DM})$, showed improved degradation levels. In Table 7 , the treatments were varied with varying levels of degradation of glucosinolate. S. cariocanus or W. anomalus significantly decreased the glucosinolate level $(\mathrm{p}<0.05)$ compared to the control group. However, in comparison to the control group, SC4 (S. cariocanus with $5 \times 10^{9} \mathrm{CFU} / \mathrm{kg} \mathrm{DM}$ ) and WA4 ( $W$. anomalus with $5 \times 10^{9} \mathrm{CFU} / \mathrm{kg} \mathrm{DM}$ ) showed better reductions in glucosinolate levels than the control group, except for the fermented control group. The biological meaning of our result is that we have not seen any nature and size of relevant biological changes or differences between the results. Therefore, that means our result has not shown any biological effect of chemical composition on TMR

\section{DISCUSSION}

The quantity of both RNA and DNA provides an indication of active cells, starved or dead cells. Both DNA/RNA of $L$. plantarum were lower compared with $B$. clausii examined by real-time PCR, indicating that most L. plantarum was no longer active. Our results concur the finding that L. plantarum incubated in glycerol 2-phosphate buffer possessed extremely low RNA/DNA ratios [37]. Similarly, the number of copies of both DNA \& RNA of S. cariocanus also was higher than that of W. anomalus.

In the current study, the supplementation of different levels of LAB or yeast effectively decreased the anti-nutritional

Table 7. Effect of yeast strains on free gossypol/glucosinolate degradation (as-DM basis)

\begin{tabular}{|c|c|c|c|c|c|c|c|c|c|c|c|c|}
\hline \multirow{2}{*}{ Items } & \multirow{2}{*}{ Control } & \multirow{2}{*}{ F Control } & \multicolumn{4}{|c|}{ Saccharomyces cariocanus ${ }^{1)}$} & \multicolumn{4}{|c|}{ Wickerhamomyces anomalus ${ }^{1)}$} & \multirow{2}{*}{ SEM } & \multirow{2}{*}{ p-value } \\
\hline & & & SC1 & $\mathrm{sc2}$ & SC3 & SC4 & WA1 & WA2 & WA3 & WA4 & & \\
\hline \multicolumn{13}{|l|}{ CSM based TMR } \\
\hline $\mathrm{FG}(\mu \mathrm{mol} / \mathrm{g})$ & $92.94^{c}$ & $77.18^{\mathrm{bc}}$ & $57.82^{a b}$ & $57.75^{\mathrm{ab}}$ & $54.17^{\mathrm{a}}$ & $52.23^{\mathrm{a}}$ & $56.59^{a}$ & $50.64^{\mathrm{a}}$ & $61.21^{\mathrm{ab}}$ & $56.63^{\mathrm{a}}$ & 2.55 & $<0.001$ \\
\hline \multicolumn{13}{|l|}{ RSM-based TMR } \\
\hline GSLs $(\mu \mathrm{mol} / \mathrm{g})$ & $18.45^{\mathrm{a}}$ & $7.71^{\mathrm{b}}$ & $6.38^{b}$ & $6.87^{b}$ & $6.05^{b}$ & $5.97^{\mathrm{b}}$ & $6.09^{b}$ & $8.57^{b}$ & $7.09^{b}$ & $6.02^{b}$ & 0.71 & $<0.001$ \\
\hline
\end{tabular}

DM, dry matter; SEM, pooled standard error of means; CSM, cottonseed meal; TMR, total mixed ration; FG, free gossypol; RSM, rapeseed meal; GSLs, glucosinolates.

1) Treatments including control with no inoculant, F control, fermented control without inoculum; SC1, Saccharomyces cariocanus with $5 \times 10^{6} \mathrm{CFU} / \mathrm{kg}$ DM; SC2, Saccharomyces cariocanus with $5 \times 10^{7}$ CFU/kg DM; SC3, Saccharomyces cariocanus with $5 \times 10^{8}$ CFU/kg DM; SC4, Saccharomyces cariocanus with $5 \times 10^{9} \mathrm{CFU} / \mathrm{kg}$ DM; WA1, Wickerhamomyces anomalus with $5 \times 10^{6} \mathrm{CFU} / \mathrm{kg} \mathrm{DM}$; WA2, Wickerhamomyces anomalus with $5 \times 10^{7} \mathrm{CFU} / \mathrm{kg}$ DM; WA3, Wickerhamomyces anomalus with $5 \times 10^{8} \mathrm{CFU} / \mathrm{kg}$ DM; WA4, Wickerhamomyces anomalus with $5 \times 10^{9} \mathrm{CFU} / \mathrm{kg} \mathrm{DM}$; CFU, colony-forming units.

${ }^{a-c}$ Means in the same columns with different superscripts differed $(p<0.05)$. 
factors and increased nutritional value of fermented TMR containing CSM or RSM. The supplementation of L. plantarum or B. clausii to TMR with CSM increased the CP content, consistent with a previous study indicating solidstate fermentation (SSF) using B. subtilis BJ-1 increased CP content from $46.5 \%$ to $50.5 \%$ [22]. Similarly, when CSM was inoculated with B. subtilis ST-141 and Saccharomycetes N5, CP increased from $49.8 \%$ to $51 \%$ [38]. On the other hand, inoculation with $L$. plantarum or B. clausii to TMR with RSM also increased the $\mathrm{CP}$ content. The highest CP value $(13.82 \%)$ was shown in $\mathrm{BC} 3$ (B. clausii with $1 \times 10^{10}$ $\mathrm{CFU} / \mathrm{kg}$ DM). These results agree with Fazhi et al [39] who found that $L$. plantarum and B. subtilis increased the CP content of fermented RSM. Similar results were also observed when L. fermentum and B. subtilis have been inoculated [40]. The increase in $\mathrm{CP}$ content could be due to the multiplication of the microorganisms responsible for the rise in protein used by the high availability of soluble carbohydrates.

Although there was no significant difference among the DM contents of both fermented TMR with CSM/RSM, it slightly reduced when fermented TMRs with CSM or RSM were inoculated with $L$. plantarum, B. clausii, S. cariocanus and $W$. anomalus at different levels. These results may be due to the loss of DM in fermented TMR with CSM or RSM, which causes a relative rise in the concentration of these nutrients. A rise in $\mathrm{CP}$ content may be a result of decrease in DM content. Our findings are consistent with the study of Wang et al [38] who discovered that when CSM was inoculated with B. subtilis ST-141 and Saccharomycetes N5, the DM content was decreased. In agreement with the present study, SSF led to reduced DM content of RSM [41]. The decrease in DM content could be a result of a decreased number of microorganisms utilizing carbohydrate consumption as an energy source for growth and survival. According to Rozan et al [42], reducing DM content during fermentation may account for the increase in $\mathrm{CP}$, the content of which was increased following fermentation. Besides, Schmidt et al [43] reported that an addition of homolactic L. plantarum, Enterococcus faecium, and heterolactic L. Brevis in ensilage of sugarcane, which indicated a domination of homolactic fermentation, with an rise in lactic acid and ethanol content, and reduced DM (43 g/kg DM; 186 g/kg DM, and 272 g/kg $\mathrm{DM}$, respectively) relative to control (36 g/kg DM; $144 \mathrm{~g} / \mathrm{kg}$ $\mathrm{DM}$, and $144 \mathrm{~g} / \mathrm{kg}$ DM respectively). The increase in NDF showed that the inoculated microbial dosage levels of the treated TMR with RSM were insufficient to control these rises in NDF of TMR with RSM. Our result were consistent with previous studies [44] that reported CF content was often elevated or slightly reduced after fermentation. Moreover, Pedroso et al [45] reported that NDF and ADF levels were increased during silage processing in the DM loss of soluble carbohydrates such as gasses and effluents. The in- crease in NDF may be attributed to the loss of DM, degradation of glucosinolates, and inadequate fiber hydrolysis during the fermentation process of TMR with RSM. The possible accumulation of acid, alkaline and neutral detergent insoluble substances during SSF can also be stated as another cause for this observation $[46,47]$, thus overstating the NDF and ADF levels. The increases in NDF may suggest that the inoculum dosage of L. plantarum, B. clausii, S. cariocanus, $W$. anomalus were insufficient to control these increases of NDF and DM loss of TMR with RSM.

Our result of FG degradation was lower than that reported by Tang et al [22], which reduced FG in solid-state fermented cotton meal from 0.82 to $0.21 \mathrm{~g} / \mathrm{kg}$. Similarly, FG reduced from 90 to $30 \mathrm{mg} / \mathrm{kg}$ in the study by Xiong et al [48]. Sun et al [49] found fermented CSM by B. subtilis BJ- supplement significantly reduced FG level and increased CP level. Comparably, Wang et al [38] stated that the fermented CSM by $B$. subtilis ST-141 and Saccharomycetes N5 dramatically reduced the FG level (from 820 to $346 \mathrm{mg} / \mathrm{kg}$ ). But the result in our study is higher than that reported by Duodu et al [50] where FG level was reduced by approximately $17 \%$ during short-term fermentation with yeast (S. cerevisiae). However, a reduction in FG level was shown in TMR with CSM during microbial fermentation. In addition to the nutritional improvement of TMR with CSM, the level of FG in TMR were significantly lowered due to fermentation with varying dosage levels of microbial strains. The reduction of FG may be the result of gossypol being bound to microbial enzymes that work to break down gossypol during the fermentation of TMR with CSM. For these reasons, considering the decreased FG level and increased CP content, SC4 (S. cariocanus with $5 \times 10^{9} \mathrm{CFU} / \mathrm{kg}$ $\mathrm{DM}$ ) and $\mathrm{BC} 2\left(\right.$ B. clausii with $\left.1.0 \times 10^{9} \mathrm{CFU} / \mathrm{kg} \mathrm{DM}\right)$ were selected as the most suitable strains for the subsequent experiment.

Our result of glucosinolate degradation is consistent with previous study, which decreased glucosinolate content from 41.91 to $23.86 \mu \mathrm{mol} / \mathrm{g}$ [51]. In line with the earlier findings of Ahmed et al [52], the current findings revealed that the increased protein content by solid-state fermentation with Lactobacillus salivarius was from $41.2 \%$ to $42.2 \%$, and the reduction in glucosinolates was from 22 to $13.6 \mathrm{mmol} / \mathrm{g}$. Likewise, it was reported that fermentation of RSM with Lactobacillus fermentum, B. subtilis, S. cerevisiae, and Enterococcus faecium decreased the isothiocyanates (derivatives of glucosinolates) and increased the CP content [40,41]. Reduced glucosinolates and increased CP content were observed during fermentation of RSM by $[11,53]$. The loss of glucosinolates led to the creation of glucose and sulphur molecules through microbial enzymes during fermentation [6]. Considering the glucosinolate-degrading ability, increased protein, and decreased NDF, both BC3 (B. clausii with $1.0 \times 10^{10} \mathrm{CFU} / \mathrm{kg}$ $\mathrm{DM})$ and SC4 (S. cariocanus with $\left.5 \times 10^{9} \mathrm{CFU} / \mathrm{kg} \mathrm{DM}\right)$ were 
selected to conduct the next experiment.

\section{CONCLUSION}

This study demonstrates that $B$. clausii with $1.0 \times 10^{9} / 1.0 \times 10^{10}$ $\mathrm{CFU} / \mathrm{kg}$ DM and S. cariocanus with $5 \times 10^{9} \mathrm{CFU} / \mathrm{kg} \mathrm{DM}$ capable of degrading anti-nutritional factors as well as improving the nutritional value of fermented TMR with CSM/RSM is beneficial. We found the decrease in the concentrations of anti-nutritional factors and enhancement of nutritional value of a fermented TMR containing CSM/RSM, and thus recommended that this fermented source of protein can be used as an appropriate alternative to SBM in ruminant diets. Further studies need to be conducted on the feed nutrient values and the safety of the original fermented groups, the mixed of strains of LAB and yeast, different dosage levels, and rate of application for optimizing the beneficial effects for the development of the nutritional value and anti-nutritional factors of the next generation of the TMR with CSM/RSM inoculant.

\section{CONFLICT OF INTEREST}

We certify that there is no conflict of interest with any financial organization regarding the material discussed in the manuscript.

\section{FUNDING}

This study was funded by the Agricultural Sciences and Technology Innovation Program (CAAS-ASTIP-2017-FRI-04, China) and by China Agriculture Research System of MOF and MARA.

\section{REFERENCES}

1. Zhang Y, Zhang Z, Dai L, Liu Y, Cheng M, Chen L. Isolation and characterization of a novel gossypol-degrading bacteria Bacillus subtilis strain rumen Bacillus Subtilis. Asian-Australas J Anim Sci 2018;31:63-70. https://doi.org/10.5713/ajas.17. 0018

2. Francis G, Makkar HPS, Becker K. Antinutritional factors present in plant-derived alternate fish feed ingredients and their effects in fish. Aquaculture 2001;199:197-227. https:// doi.org/10.1016/S0044-8486(01)00526-9

3. Robinson PH, Getachew G, De Peters EJ, Calhoun MC. Influence of variety and storage for up to 22 days on nutrient composition and gossypol level of Pima cottonseed (Gossypium spp.). Anim Feed Sci Technol 2001;91:149-56. https:// doi.org/10.1016/S0377-8401(01)00202-4

4. Ashayerizadeh A, Dastar B, Shargh MS, Mahoonak AS, Zerehdaran S. Effects of feeding fermented rapeseed meal on growth performance, gastrointestinal microflora popul- ation, blood metabolites, meat quality, and lipid metabolism in broiler chickens. Livest Sci 2018;216:183-90. https://doi. org/10.1016/j.livsci.2018.08.012

5. Wanasundara JPD, Tan S, Alashi AM, Pudel F, Blanchard C. Chapter 18 - Proteins From Canola/Rapeseed: Current Status. In: Nadathur SR, Wanasundara JPD, Scanlin L, editors. Sustainable protein sources. San Diego, CA, USA: Academic Press; 2017. p. 285-304.

6. Tripathi MK, Mishra AS. Glucosinolates in animal nutrition: a review. Anim Feed Sci Technol 2007;132:1-27. https://doi. org/10.1016/j.anifeedsci.2006.03.003

7. Huisman J, Tolman G. Antinutritional factors in the plant proteins of diets for non-ruminants. Recent Adv Anim Nutr 1992;68:101-10.

8. Nagalakshmi D, Sastry VRB, Pawde A. Rumen fermentation patterns and nutrient digestion in lambs fed cottonseed meal supplemental diets. Anim Feed Sci Technol 2003;103:1-14. https://doi.org/10.1016/S0377-8401(02)00140-2

9. Tabatabai F, Golian A, Salarmoeini M. Determination and detoxification methods of cottonseed meal gossypol for broiler chicken rations. Agric Sci Technol 2002;16:3-15.

10. Weng X-Y, Sun J-Y. Biodegradation of free gossypol by a new strain of Candida tropicalis under solid state fermentation: Effects of fermentation parameters. Process Biochem 2006;41: 1663-8. https://doi.org/10.1016/j.procbio.2006.03.015

11.Pal Vig A, Walia A. Beneficial effects of Rhizopus oligosporus fermentation on reduction of glucosinolates, fibre and phytic acid in rapeseed (Brassica napus) meal. Bioresour Technol 2001;78:309-12. https://doi.org/10.1016/S0960-8524(01)00 030-X

12. Ryu C-H, Park M-S, Park C, Choi N-J, Cho S-B. Fermentation of environmental friend total mixed ration and alteration of rumen fermentation characteristics. Korean J Org Agric 2017; 25:461-73.

13. Suntara C, Cherdthong A, Uriyapongson S, Wanapat M, Chanjula P. Novel crabtree negative yeast from rumen fluids can improve rumen fermentation and milk quality. Sci Rep 2021;11:6236. https://doi.org/10.1038/s41598-021-85643-2

14. Navarro DMD, Liu Y, Bruun TS, Stein HH. Amino acid digestibility by weanling pigs of processed ingredients originating from soybeans, 00 -rapeseeds, or a fermented mixture of plant ingredients. J Anim Sci 2017;95:2658-69. https:// doi.org/10.2527/jas.2016.1356

15.Tomaszewska E, Muszyński S, Dobrowolski P, et al. Dried fermented post-extraction rapeseed meal given to sows as an alternative protein source for soybean meal during pregnancy improves bone development of their offspring. Livest Sci 2019;224:60-8. https://doi.org/10.1016/j.livsci.2019.04.009

16.Sun H, Tang JW, Yao XH, Wu YF, Wang X, Feng J. Effects of dietary inclusion of fermented cottonseed meal on growth, cecal microbial population, small intestinal morphology, and digestive enzyme activity of broilers. Trop Anim Health 
Prod 2013;45:987-93. https://doi.org/10.1007/s11250-0120322-y

17.Shurson GC. Yeast and yeast derivatives in feed additives and ingredients: Sources, characteristics, animal responses, and quantification methods. Anim Feed Sci Technol 2018; 235:60-76. https://doi.org/10.1016/j.anifeedsci.2017.11.010

18.Zhang WJ, Xu ZR, Zhao SH, Sun JY, Yang X. Development of a microbial fermentation process for detoxification of gossypol in cottonseed meal. Anim Feed Sci Technol 2007; 135:176-86. https://doi.org/10.1016/j.anifeedsci.2006.06.003

19. Shi C, He J, Yu J, et al. Solid state fermentation of rapeseed cake with Aspergillus niger for degrading glucosinolates and upgrading nutritional value. J Anim Sci Biotechnol 2015;6:13. https://doi.org/10.1186/s40104-015-0015-2

20. Adeyemo SM, Onilude AA. Enzymatic reduction of antinutritional factors in fermenting soybeans by lactobacillus plantarum isolates from fermenting cereals. Niger Food J 2013;31:84-90. https://doi.org/10.1016/S0189-7241(15)300 80-1

21.Sun H, Yao X, Wang X, et al. Chemical composition and in vitro antioxidant property of peptides produced from cottonseed meal by solid-state fermentation. CYTA J Food 2015; 13:264-72. https://doi.org/10.1080/19476337.2014.948072

22. Tang JW, Sun H, Yao XH, Wu YF, Wang X, Feng J. Effects of replacement of soybean meal by fermented cottonseed meal on growth performance, serum biochemical parameters and immune function of yellow-feathered broilers. Asian-Australas J Anim Sci 2012;25:393-400. https://doi.org/10.5713/ajas. 2011.11381

23. Sun H, Tang JW, Fang CL, et al. Molecular analysis of intestinal bacterial microbiota of broiler chickens fed diets containing fermented cottonseed meal. Poult Sci 2013;92:392-401. http:// doi.org/10.3382/ps.2012-02533

24. Cherdthong A, Suntara C, Khota W, Wanapat M. Feed utilization and rumen fermentation characteristics of Thai-indigenous beef cattle fed ensiled rice straw with Lactobacillus casei TH14, molasses, and cellulase enzymes. Livest Sci 2021;245:104405. https://doi.org/10.1016/j.livsci.2021.104405

25.Chen L, Guo G, Yuan X, Zhang J, Li J, Shao T. Effects of applying molasses, lactic acid bacteria and propionic acid on fermentation quality, aerobic stability and in vitro gas production of total mixed ration silage prepared with oatcommon vetch intercrop on the Tibetan Plateau. J Sci Food Agric 2016;96:1678-85. https://doi.org/10.1002/jsfa.7271

26.Urdaci MC, Bressollier P, Pinchuk I. Bacillus clausii probiotic strains: antimicrobial and immunomodulatory activities. J Clin Gastroenterol 2004;38:S86-90. https://doi.org/10.1097/ 01.mcg.0000128925.06662.69

27. Olukomaiya O, Fernando C, Mereddy R, Li X, Sultanbawa Y. Solid-state fermented plant protein sources in the diets of broiler chickens: a review. Anim Nutr 2019;5:319-30. https:// doi.org/10.1016/j.aninu.2019.05.005
28. Plaipetch P, Yakupitiyage A. Effect of replacing soybean meal with yeast-fermented canola meal on growth and nutrient retention of Nile tilapia, Oreochromis niloticus (Linnaeus 1758). Aquac Res 2014;45:1744-53. https://doi.org/10.1111/ are.12119

29. Suntara C, Cherdthong A, Uriyapongson S, Wanapat M, Chanjula P. Comparison effects of ruminal Crabtree-negative yeasts and Crabtree-positive yeasts for improving ensiled rice straw quality and ruminal digestion using in vitro gas production. J Fungi 2020;6:109. https://doi.org/10.3390/ jof6030109

30.Dashko S, Zhou N, Compagno C, Piškur J. Why, when, and how did yeast evolve alcoholic fermentation? FEMS Yeast Res 2014;14:826-32. https://doi.org/10.1111/1567-1364.12161

31. Kim SH, Alam MJ, Gu MJ, et al. Effect of total mixed ration with fermented feed on ruminal in vitro fermentation, growth performance and blood characteristics of Hanwoo steers. Asian-Australas J Anim Sci 2012;25:213-23. https://doi.org/ 10.5713/ajas.2011.11186

32.Nie C, Zhang W, Ge W, Liu YF, Wang YQ, Liu JC. Effect of cottonseed meal fermented with yeast on the lipid-related gene expression in broiler chickens. Braz J Poult Sci 2015; 17:57-64. https://doi.org/10.1590/1516-635XSPECIAL ISSUENutrition-PoultryFeedingAdditives057-064

33. Horwitz W. Official methods of analysis. Washington, DC, USA: Association of Official Analytical Chemists; 1975.

34. Van Soest PJ, Robertson JB, Lewis BA. Methods for dietary fiber, neutral detergent fiber, and nonstarch polysaccharides in relation to animal nutrition. J Dairy Sci 1991;74:3583-97. https://doi.org/10.3168/jds.S0022-0302(91)78551-2

35. AOCS. Free and total gossypol methods. Official and tentative methods. Champaign, IL, USA: AOCS; 1999.

36. Wathelet JP, Wagstaffe PJ, Biston R, Marlier M, Severin M. Rapeseed reference materials for glucosinolate analysis. Z Anal Chem 1988;332:689-93. https://doi.org/10.1007/BF004 72670

37. Marco ML, Kleerebezem M. Assessment of real-time RT-PCR for quantification of Lactobacillus plantarum gene expression during stationary phase and nutrient starvation. J Appl Microbiol 2008;104:587-94. https://doi.org/10.1111/j.13652672.2007.03578.x

38. Wang, Deng Q, Song D, et al. Effects of fermented cottonseed meal on growth performance, serum biochemical parameters, immune functions, antioxidative abilities, and cecal microflora in broilers. Food Agric Immunol 2017;28:725-38. https:// doi.org/10.1080/09540105.2017.1311308

39. Fazhi, Lvmu L, Jiaping X, Kun Q, Zhide Z, Zhangyi L. Effects of fermented rapeseed meal on growth performance and serum parameters in ducks. Asian-Australas J Anim Sci 2011;24:678-84. https://doi.org/10.5713/ajas.2011.10458

40.Xu FZ, Zeng XG, Ding XL. Effects of replacing soybean meal with fermented rapeseed meal on performance, serum bio- 
chemical variables and intestinal morphology of broilers. Asian-Australas J Anim Sci 2012;25:1734-41. https://doi. org/10.5713/ajas.2012.12249

41.Chiang G, Lu WQ, Piao XS, Hu JK, Gong LM, Thacker PA. Effects of feeding solid-state fermented rapeseed meal on performance, nutrient digestibility, intestinal ecology and intestinal morphology of broiler chickens. Asian-Australas J Anim Sci 2010;23:263-71. https://doi.org/10.5713/ajas.2010. 90145

42. Rozan P, Villaum C, Bau HM, Schwertz A, Nicolas JP, Méjean L. Detoxication of rapeseed meal by Rhizopus Oligosporus sp-T3: A first step towards rapeseed protein concentrate. Int J Food Sci Technol 1996;31:85-90. https://doi.org/10.1111/ j.1365-2621.1996.17-315.x

43. Schmidt P, Rossi Junior P, Junges D, Dias LT, Almeida R, Mari LJ. New microbial additives on sugarcane ensilage: Bromatological composition, fermentative losses, volatile compounds and aerobic stability. Rev Bras Zootec 2011;40:543-9. https://doi.org/10.1590/S1516-35982011000300011

44. Rajesh N, Imelda J, Raj RP. Value addition of vegetable wastes by solid-state fermentation using Aspergillus niger for use in aquafeed industry. Waste Manag 2010;30:2223-7. https:// doi.org/10.1016/j.wasman.2009.12.017

45.Pedroso, Nussio LG, Loures DRS, et al. Effect of chemical and bacterial additives on losses and quality of sugar cane silages. Rev Bras Zootec 2007;36:558-64. https://doi.org/10. 1590/S1516-35982007000300006

46. Olukomaiya OO, Adiamo OQ, Fernando WC, Mereddy R, Li X, Sultanbawa Y. Effect of solid-state fermentation on proximate composition, anti-nutritional factor, microbiological and functional properties of lupin flour. Food Chem 2020;315:126238. https://doi.org/10.1016/j.foodchem.2020. 126238
47. Ramli MN, Imura Y, Takayama K, Nakanishi Y. Bioconversion of sugarcane bagasse with Japanese koji by solid-state fermentation and its effects on nutritive value and preference in goats. Asian-Australas J Anim Sci 2005;18:1279-84. https:// doi.org/10.5713/ajas.2005.1279

48.Xiong JL, Wang ZJ, Miao LH, Meng FT, Wu LY. Growth performance and toxic response of broilers fed diets containing fermented or unfermented cottonseed meal. J Anim Feed Sci 2016;25:348-53. https://doi.org/10.22358/jafs/67667/ 2016

49. Sun H, Tang JW, Fang CL, et al. Molecular analysis of intestinal bacterial microbiota of broiler chickens fed diets containing fermented cottonseed meal. Poult Sci 2013;92:392401. https://doi.org/10.3382/ps.2012-02533

50.Duodu CP, Adjei-Boateng D, Edziyie RE, et al. Processing techniques of selected oilseed by-products of potential use in animal feed: Effects on proximate nutrient composition, amino acid profile and antinutrients. Anim Nutr 2018;4: 442-51. https://doi.org/10.1016/j.aninu.2018.05.007

51.Shi C, He J, Yu J, et al. Physicochemical properties analysis and secretome of aspergillus niger in fermented rapeseed meal. PLoS One 2016;11:e0153230. https://doi.org/10.1371/ journal.pone. 0153230

52. Ahmed A, Zulkifli I, Farjam AS, Abdullah N, Liang JB, Awad EA. Effect of solid state fermentation on nutrient content and ileal amino acids digestibility of canola meal in broiler chickens. Ital J Anim Sci 2014;13:3293. https://doi.org/10. 4081/ijas.2014.3293

53. Hu Y, Wang Y, Li A, et al. Effects of fermented rapeseed meal on antioxidant functions, serum biochemical parameters and intestinal morphology in broilers. Food Agric Immunol 2016;27:182-93. https://doi.org/10.1080/09540105.2015.107 9592 